\section{Where's the Productivity Growth (from the Information Technology Revolution)?}

\section{Donald S. Allen}

Gutenberg invented movable type. It took another 40 years for an entrepreneur named Aldus to assemble what created book publishing as we know it. Marconi invented radio exactly 100 years ago. It took another 25 years for entrepreneurs in Pittsburgh and New York to create broadcasting. It was through broadcasting that radio reshaped our lives.

Scott Cook, Chairman, Intuit

Forbes ASAP, October 9, 1995

\footnotetext{
T
} echnology- especially information technology (IT) - has demonstrated phenomenal growth over the last few decades, while the growth of business-sector productivity in the United States has been relatively modest, seeming to belie the much-ballyhooed information technology revolution. If computer usage has exploded so dramatically, and if computers contribute to increased efficiency, some people are asking, where is the associated productivity growth? There are actually two parts to the question. First, are IT investments improving productivity? Second, if they are, why don't the aggregate numbers reflect this? The essence of this puzzle is captured by Robert Solow's quip that computers are everywhere "except in the productivity statistics."
Solow's observation produced a spate of research to explain this apparent puzzle. Three explanations coming out of this research will be discussed in this article: measurement difficulties, the small proportion of capital stock that computers represent, and the concept that diffusion of changing work methods is still under way.

The following section shows some of the trends in investment in IT and the corresponding trends in output per hour for total business and manufacturing. It then looks at some selected industries to see if the IT/productivity growth nexus exists at this level of aggregation. The next section analyzes the three explanations offered for the apparent puzzle. The fourth section offers some tentative predictions for when the latent productivity will begin to have an impact on the statistics. Finally, I offer some conclusions about the relation between information technology and productivity growth.

\section{INVESTMENT AND PRODUCTIVITY TRENDS}

The proliferation of cellular phones, pagers, and desktop and laptop computers in the last few years provides some very obvious examples of the rapid advances in information technology over the last two decades. Investment statistics also bear out the increases in IT usage. Table 1 shows (1) the total private nonresidential fixed investment (PNFI) in chain-weighted 1992 dollars, (2) the share of this investment attributable to producers' durable equipment (PDE), (3) the informationprocessing and related equipment component of this share, and (4) the portion of this component made up of computers and peripheral equipment.

The portion of computers in total nonresidential fixed investment increased from less than one-tenth of 1 percent of total PNFI in 1970 to 12.8 percent by 1995. During this period, information processing equipment increased from 7.2 percent of 
Table 1

\section{Investment by Category}

(chain-weighted, billions of 1992 dollars)

\begin{tabular}{lrrrrr}
\cline { 3 - 6 } & & 1970 & 1980 & 1990 & 1995 \\
\cline { 3 - 6 } Nonresidential fixed investment & & 282.8 & 461.2 & 585.2 & 714.3 \\
Producers' durable equipment (PDE) & 149.5 & 268.3 & 381.9 & 534.4 \\
Information processing equipment (IPE) & 10.7 & 45.5 & 116.2 & 201.2 \\
Computers and peripherals (CPE) & 0.1 & 2.4 & 29.4 & 91.5
\end{tabular}

${ }^{1}$ If we consider IT investment as a substitute for labor, then ITinduced productivity increases will be accompanied by labor reduction. The clear winners at the industry level display flat or declining employment over the period, but some slow growers show dedining employment with low-output growth. This finding is consistent with those of Baily, Bartelsman, and Haltiwanger (1994) that show aggregate manufacturing productivity gains have been boosted about equally by firms that downsized and gained productivity improvement and those that increased employment and productivity. The authors also found firms that had downsized and had decreased labor productivity.

2 The increasing complexity of new automobiles is the most likely reason for the high growth rate of IT investment in automobile repair. It could be argued that automobile repair services should therefore be adjusted for quality to reflect the increased level of complexity. If this is not done, productivity is likely to be underestimated.
PDE in 1970 to 37.6 percent by the end of 1995. Expressed another way, investment in information processing equipment increased more than 1800 percent, while total PNFI increased about 250 percent. Figure 1 shows quarterly data for each of these components over the period. The accelerated growth over the last decade is obvious.

By comparison, productivity growth measures were more meager. Table 2 shows productivity growth rates for total business, the nonfarm business sector, the manufacturing sector, and the durable goods manufacturing sector. Whereas investment in information processing equipment grew at an annual rate of 12.5 percent over the period, productivity gains ranged from 1.3 annually for nonfarm business to 3.3 percent annually for manufacturing durables. Figure 2 shows that manufacturing productivity has trended up more steeply in the last few years, but when it is aggregated with nonmanufacturing productivity, the total is less impressive. This cursory look at the aggregate statistics suggests that there has been no phenomenal productivity growth from the rapid growth in IT.

\section{Industry-Level Productivity}

Recent studies at the firm level have documented gains in productivity from IT investment. Brynjolfsson and Hitt (1996b), for example, found productivity gains at the firm level for institutions investing in IT. Brynjolfsson and Hitt (1996a) estimate that the gross rate of return on investment in computers exceeds 50 percent annually, compared to 15 percent to 20 percent for other investments, in the sample of firms that they analyzed. They conclude that the productivity paradox at the firm level has disappeared since 1991. High labor productivity growth can be identified in selected sectors of the economy also, but the missing aggregate productivity still begs explanation.

Table 3 shows productivity growth rates from 1970 to 1994 for eight selected manufacturing and service sectors and the growth of investment in IT in these industries. The above-average performers include railroad transportation, where productivity grew at an average of 6.3 percent annually between 1970 and 1992; the telephone communication industry, where productivity growth averaged 5.7 percent annually between 1970 and 1994; and the steel industry, which averaged 4.2 percent annually over the same period. The productivity growth in these industries coincided with high rates of investment in IT. ${ }^{1}$

The below-average-productivity growth sectors shown in Table 3 include crude petroleum and natural gas ( -1.7 percent annually), gas utilities (-1.4 percent annually), laundry, cleaning, and garment services (no growth over the period), and automotive repair shops ( 0.1 percent annually). The average rate of growth in IT investment for below-average performers has been higher than for some of the aboveaverage performers. Automotive repair shops recorded a 24.4 percent average annual growth rate of investment in IT, but only a 0.1 percent annual growth in productivity. ${ }^{2}$ As the table shows, IT investment growth seems to bear no correlation to productivity growth for below-average performers. As a result, a breakdown of investments by sector sheds no immediate light on the relationship of IT to productivity.

Looking at the levels of investment in IT per employee lends some perspective to the productivity performance, but not much. The telephone communication industry has the highest ratio of IT investment per employee, as one might expect, 


\section{Table 2}

\section{Output Per Hour}

(five-year compounded annual rates of change in percent)

\begin{tabular}{lccccccc} 
& & $\mathbf{1 9 7 0 - 7 5}$ & $\mathbf{1 9 7 5 - 8 0}$ & $\mathbf{1 9 8 0 - 8 5}$ & $\mathbf{1 9 8 5 - 9 0}$ & $\mathbf{1 9 9 0 - 9 5}$ & $\mathbf{1 9 7 0 - 9 5}$ \\
\cline { 1 - 6 } \cline { 3 - 7 } Business sector & 2.5 & 1.1 & 1.8 & 0.9 & 1.0 & 1.5 \\
Nonfarm business sector & & 2.4 & 1.0 & 1.4 & 0.8 & 1.0 & 1.3 \\
Manufacturing sector & 3.4 & 1.8 & 3.3 & 2.4 & 3.1 & 2.8 \\
Durables & 3.6 & 1.6 & 3.6 & 3.4 & 4.1 & 3.3
\end{tabular}

and it is an above-average performer in labor productivity measure. But gas utilities also show high levels of IT investment per employee without the corresponding productivity growth. The telephone industry is capital intensive, and service is an integral part of its output, as it is for electric utilities and railroads. This similarity might provide some insight into the characteristics that enable firms to achieve increased productivity from IT. The next section looks at the electric utility sector experience in a little more detail.

\section{Anecdote on Electric Utility Productivity.}

The electric utility industry is a service industry. Unlike many service industries, however, it provides a highly measurable commodity as well. The production of energy is a highly capital and fuel-

intensive process. ${ }^{3}$ Perhaps for this reason, the electric utility industry has led the charge toward increased use of information technology. Advances in microelectronics have allowed utilities to automate control systems and data acquisition in the field and to integrate these systems with state-of-the-art personal computing hardware. When the economy-wide explosion in computer systems use occurred in the late 1980s for the U.S. economy, electric utilities were well along the path of integrating information technology into their business. Figure 3 shows total electric utility investment in equipment and structures and investment in information processing. Total utility investment increased substantially in the mid-1980s, going from $\$ 7.9$ billion in 1970 to a peak of $\$ 41.4$ billion in 1985 and tapering off

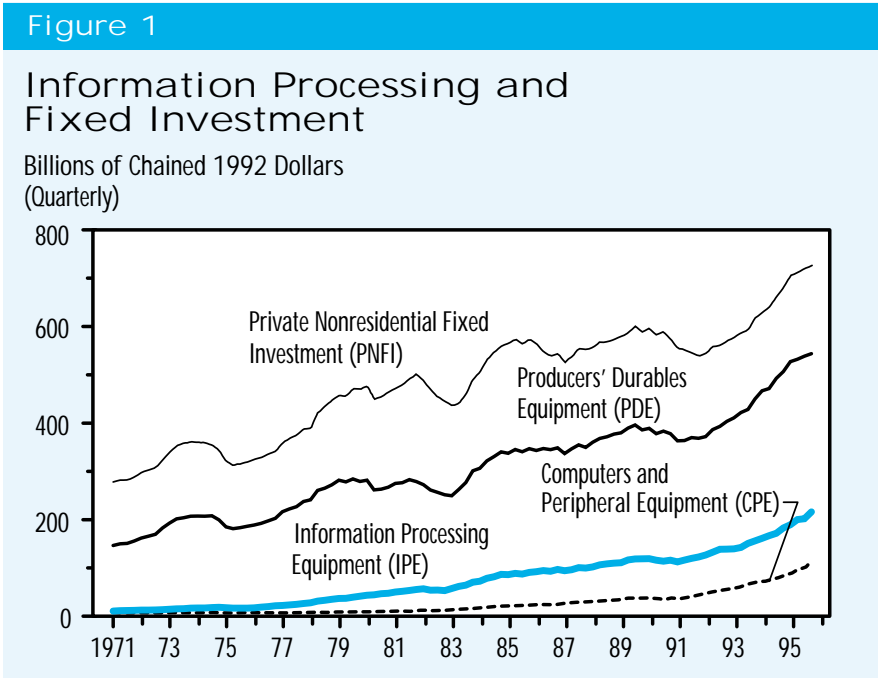

\section{Figure 2}

\section{Output Per Hour}

Quarterly Index $1992=100$, SA

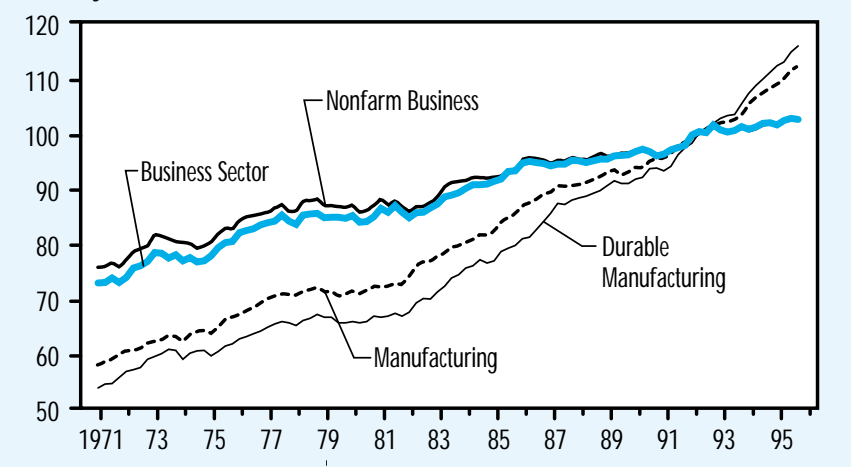

after this period. During this time electric utilities' annual investment in information technology increased from $\$ 216$ million to $\$ 4,792$ million by 1987 . The office computing and accounting category accounted
3 Customer service provided by the electric utility is also an integral part of the service it provides, but this portion of "output" is unmeasured in the productivity statistics. 


\section{Table 3}

\section{Average Annual Growth Rates of Output Per Hour $(\mathrm{O} / \mathrm{H})$ and Investment in Information Technology $(\text { IT })^{1}$ for Selected Industries}

\begin{tabular}{|c|c|c|c|}
\hline & \multicolumn{2}{|c|}{1970.94} & \multirow{2}{*}{$\begin{array}{c}\begin{array}{c}\text { IT Investment } \\
\text { Per Employee } 1994\end{array} \\
\text { Dollars (historical) }\end{array}$} \\
\hline & O/ H & IT & \\
\hline Total business sector & 1.5 & & \\
\hline \multicolumn{4}{|l|}{ Above-average performers } \\
\hline Railroad transportation, revenue traffic & $6.3^{2}$ & 13.9 & 6,144 \\
\hline Telephone communications & 5.7 & 5.2 & 20,589 \\
\hline Steel ${ }^{3}$ & 4.2 & 7.7 & 745 \\
\hline Electric Utilities & 2.1 & 13.2 & 2,271 \\
\hline \multicolumn{4}{|l|}{ Below-average performers } \\
\hline Crude petroleum and natural gas ${ }^{3}$ & -1.7 & 13.6 & 2,229 \\
\hline Gas utilities & -1.4 & 16.6 & 5,026 \\
\hline Laundry, cleaning and garment services 3 & 0.0 & 21.1 & 783 \\
\hline Automotive repair shops & $0.1^{4}$ & 24.4 & 3,287 \\
\hline \multicolumn{4}{|c|}{${ }^{1}$ sum of investment in office computing and accounting equipment and communications equipment in historical dollars. } \\
\hline \multicolumn{4}{|c|}{$\begin{array}{l}3 \text { Data were not available for steel, crude petroleum, and natural gas, and laundry, deaning, and garment services, so data for primary } \\
\text { metals, oil and gas extraction and personal services investment were used respectively as substitutes. }\end{array}$} \\
\hline \multicolumn{4}{|l|}{${ }^{4} 1972-94}$. \\
\hline SOURCE: Bureau of Labor & & & \\
\hline
\end{tabular}

for $\$ 9$ million in 1970 and peaked at $\$ 301$ million in 1985.

This investment appears to have paid off. The electric utilities productivity growth exceeded average manufacturing growth between 1971 and 1994. Figure 4 shows the productivity index (output per employee hour), output, and number of employees indexed to 1987 for electric utilities. Productivity slowed dramatically between 1974 and 1982 but began picking up again in 1986 and exceeded output growth. Between 1990 and 1994, electric utility output per employee hour increased at a 3.8 percent annual rate, while manufacturing productivity increased at a 3.1 percent annual rate. More vividly, the 1993-94 productivity growth rate was 6.4 percent for utilities, compared to 4.3 percent for total manufacturing. Although investment peaked in the mid-1980s, the annual average for utility productivity growth from 1985 to 1990 was only 3.3 percent.

The rising labor productivity growth rate coincides with the reduction in the number of employees. The index of total utilities employees fell to 92.5 in 1994 from a peak of 100.4 in 1986 (1987=100). Meanwhile, output continued to increase, al though at a somewhat slower rate. The high rate of investment in new plant and equipment other than IT could have substituted for labor, but, given the industry's production methods, it seems more plausible that the workforce reduction resulted from investment in IT rather than from capital additions of new power plants.

W hatever the cause, IT acceleration preceded the employee reduction by about five years. The first signs of labor force reductions are observed at the peak of IT 
investment in 1986. Reducing labor input might not have been possible if the utilities had not increased their ability to exploit the potential of previously acquired information technology. This rationale for the five-year lag between initial acceleration of IT investment and increased productivity growth may not be valid for all industries, but is likely to be a reasonable starting point.

While some studies support the premise that IT investment has yielded significant returns at the firm level, the data at the industry level are mixed. At the level of the macroeconomy, there is still the gnawing puzzle that the aggregate numbers do not show a correspondingly rapid growth in productivity. The next section looks at some explanations economists have given.

\section{THREE EXPLANATIONS}

The first explanation, offered by Griliches (1994), Baily and Gordon (1988), and others, points to measurement error as one source of understated productivity growth. M easuring output is problematic, they maintain- especially in the service sector, which is not only a growing segment of the economy but an area in which computers can contribute much to productivity.

The second explanation, offered by Oliner and Sichel (1994) and others, is that computers still represent only a small fraction of total capital stock and cannot make a large impact on aggregate productivity. In other words, there is no missing productivity. Individual users and firms do gain productivity from using computers, but the gain is insignificant relative to the overall economy.

The third explanation, proposed by Paul David (1990) and others, is that it takes time for new technology- particularly a revolutionary way of structuring work methods - to become absorbed or acquired by the economy. The presence of a computer on a desk does not mean that it is used to its full potential. It may take a full generation before industries acquire the necessary skills to exploit IT advances on an economy-wide scale.

\section{Figure 3}

\section{Utility Investment}

Millions of Dollars

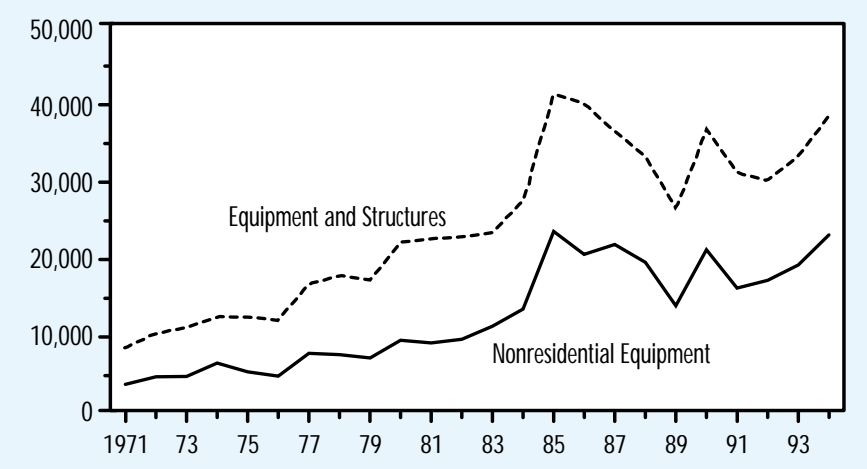

Millions of Dollars

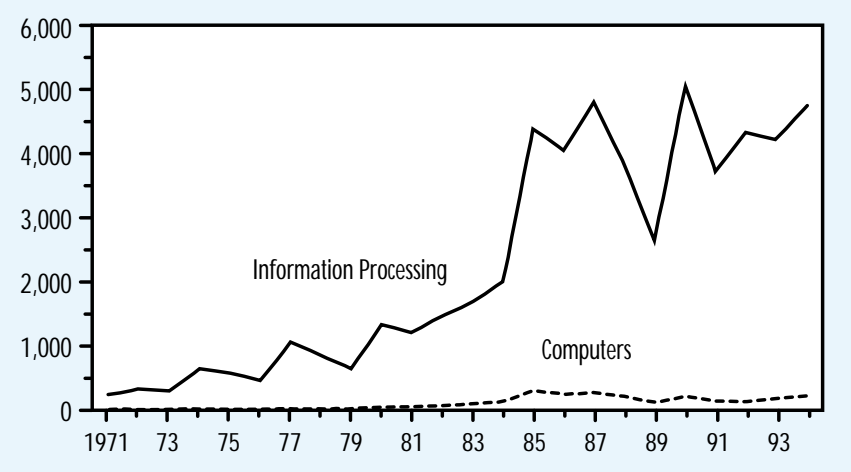

\section{Figure 4}

Labor Productivity Index for Electric Utilities $1987=100$

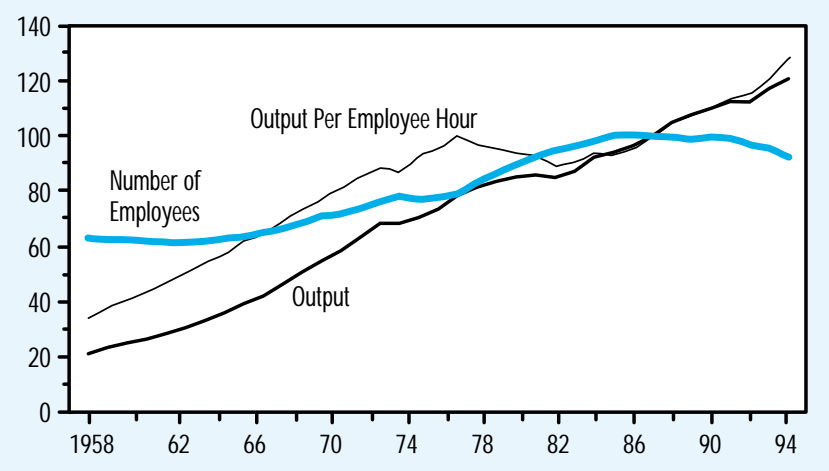




\section{The Measurement Story}

Average labor productivity is the nominal output of a sector, appropriately deflated and divided by the hours worked in that sector. Measuring each of these variables presents special difficulties. Baily and Gordon (1988) focus on the contribution of measurement to the dramatic slowdown in productivity growth in the United States after 1973. The measurement issues they address also directly address the puzzle of missing productivity growth related to computers. They state that "the explosion of computer power during the past decade is at the heart of the economy's movement toward activities that are hard for conventional methods to measure and provides a plausible reason why measurement errors might have overstated the extent of the post-1973 slowdown" (p. 350).

Official data, they point out, show that productivity in the manufacture of computers has improved dramatically, but productivity resulting from the use of computers has not. One reason they cite for the measured improvement in computer manufacturing productivity is the introduction of the so-called hedonic price index in 1986. The objective of the index is to measure "computer power" rather than computers. The hedonic index adjusts the price to reflect increases in the quality of computers by focusing on the cost of a computer calculation. This adjustment helped boost the measured productivity of the nonelectrical machinery industry by an average of 12 percent per year during the period from 1979 to 1987. The question Baily and Gordon try to answer is, What has all this computer power been doing?

Baily and Gordon's article looks at the computer-use issue in three ways. First, it looks at the types of activities for which computers are used and how these activities might be missed in the data. Second, it looks at how index-number methodology might lead to distortions in aggregate capital and output data. And third, it provides a case study of the finance, insurance, and real estate (FIRE) service sector, where computers have a major impact.

Baily and Gordon conclude that IT is providing valuable customer services that are not being picked up in the official output data. They point out that convenience, a direct contribution by computers to firm-level productivity, may not be measured in aggregate output statistics. They find an increasing number of consumer services that offer improved convenience as a result of IT; yet convenience, as a quality improvement created by computers, is not likely to be measured adequately. They cite the following examples of increased convenience from computers: In the transportation sector, airlines offer preassigned seats and boarding passes, "no-stop" check-in, frequent-flyer plans (unmeasured price reductions), reduced rates for businesspersons, and overnight package delivery services with continuous tracking. In the retail trade sector, computers provide better inventory control, fewer stock-outs, increased variety of offerings, and computerized prescription records. In the financial sector, computers help firms provide all-in-one cash management accounts, costless portfolio diversification through no-load mutual funds, automatic telephone authorizations allowing al most instantaneous credit card approvals, fast bill payment by means of phone or PC, and 24-hour money machines. Computers make it much more convenient for hotel chains to offer frequent-stayer services, no-stop check-out, and prompt, accurate room service. Restaurants, supermarkets, and hospitals provide computerproduced itemized billing.

Improved working conditions contributed by IT also go unheralded. Word processors may appreciate the easier word processing made possible by computers, but this improvement does not get measured in output changes.

The above examples are specific instances in which computers produce added convenience that might not be measured. But Baily and Gordon also recognize that improvements at the individual firm, whether measurable or not, may not always 
contribute to aggregate improvements. For instance, IT investment, in general, and computers, in particular, can improve individual firm productivity and competitiveness via more efficient information processing. If the improvement allows the firm to acquire a larger market share at the expense of less efficient firms, resulting simply in a redistribution of output, the attendant productivity improvement will not show up in aggregate data.

Baily and Gordon also question indexnumber methodology and the appropriateness of the price deflator. When computer technology improves rapidly and price deflation occurs, constant-dollar base-weighted investment series can induce distortions in measured real output. For example, if a new model of computer costs 10 percent less but is twice as powerful, the appropriate deflator should reflect a decrease in price greater than 10 percent. This quality adjustment, although partially accounted for in some industries, is not easy to do. ${ }^{4}$

When deflation is calculated relative to a base year without chaining, distortion increases as one gets further from the base year. Baily and Gordon estimate that the base-weighted index overstates the level of investment in producer durable equipment (PDE) by 3.2 percent and that real GNP was overstated by 0.8 percent for the four quarters ending in 1988:2 compared to a current-year index. The problem has been partially addressed by the BEA with the conversion to a chainweighted estimation of NIPA that also reflects adjustment for similar substitution bias in other commodities.

Finally, in their case study of the finance, insurance, and real estate (FIRE) sector, Baily and Gordon note that the method of estimating output is steeped in assumptions tying output in these sectors to labor input and to performance in the sectors they serve. The FIRE sector includes banking, credit agencies, the securities industry, insurance carriers, insurance agents, real estate, and holding and other investment companies. In the banking, credit, securities, and holding company sectors, the BEA uses labor input to extrapolate real output changes. If estimated output moves in lockstep with labor input, then only the effects of changes in composition of output will cause measured labor productivity to grow. In the insurance and real estate industries, the BEA uses rents, premiums, and commissions to estimate nominal dollar output, and various deflators to calculate constant-dollar output. Although these industries can show productivity growth, Baily and Gordon find that the deflators are inappropriate or subject to substantial error. For example, for lack of a better deflator, the deflator for insurance output uses price changes in the industries the insurance companies serve. Productivity in the insurance sector is reduced because of the escalation of cost indexes in medical care and repair services, even though these costs may not be entirely appropriate.

When Baily and Gordon use other measures of output, for example, total trades per employee in the case of the stock brokerage industry, or number of checks processed per employee in the banking sector, much better productivity growth is observed. The number of shares traded per employee in the securities industry rose from about 48,000 in 1979 to about 124,000 in 1987 . When the value of the shares traded is deflated, productivity accelerates in contrast to the labor-based estimate of output. In the banking industry, the number of checks processed per hour rose from 265 items per worker hour in 1971 to 825 items per worker hour in 1986, reflecting a 7.6 percent annual increase. Rough estimates imply that understatement of growth in the FIRE sector could have reduced post-1973 growth by as much as 2.3 percent a year in the sector. According to Baily and Gordon, only measurement difficulties that affect the aggregate economy and contribute to post-1973 slowdown are relevant to the productivity slowdown issue. Many of the difficulties they identify, such as deflation errors, affect pre-1973 and post-1973 productivity calculations roughly equally. The effects of computers appear to be relevant. On balance, however, they estimate that
${ }^{4}$ Five biases are identified in a review of fixed-weight price indexes: substitution bias, which fails to take into account shifts in household purchases caused by relative price changes; quality bias, which fails to account for changes in product quality; outlet bias, which fails to take into account the use of discount outlets by consumers; new-product bias, which fails to include new products in the basket of commodities used in developing the index; and formula bias, which derives from the method used to compute the index. 
measurement issues can account for only about " 0.5 point of the full 1.5 point slowdown."

\section{The Capital Stock Story}

The second explanation for the productivity puzzle is that despite the large increases in computer investment, computers are still only a small portion of the stock of capital. Oliner and Sichel (1994) estimate the size of the computer productivity growth puzzle by using a growthaccounting model. Growth accounting uses a production function to develop an accounting framework that attributes a share of output growth to growth in each input plus technological improvement. These researchers separate capital into computers and other capital. They estimate computers' contribution to output growth at a baseline with the assumptions that computers earn the same return as other capital, that the output of computers is correctly measured by official procedures, and that focusing on computer hardware alone is appropriate.

Oliner and Sichel present three main results: First, because computers represent only a small portion of the total capital stock, if they earned the same return as other capital, the contribution from computer investment to aggregate productivity growth would be only 0.16 percentage point per year. Second, the authors observe that concentrating on hardware al one would tend to underestimate the contribution of computers to productivity, but even when software is included, the contribution is still minimal. Finally, they conclude that recently observed upsurges in productivity are probably not likely to be due to computers.

Oliner and Sichel estimate that computer stocks were a mere 2 percent of total nonresidential equipment and structures (TNES) stock in nominal dollars in 1993. The 1993 stocks of information processing equipment were estimated to be 11.7 percent of TNES. Because of quality-adjustment decreases in deflators, the real stock of computers was estimated to be 5.1 percent of TNES. Oliner and Sichel use this proportion-along with the "usual neoclassical assumptions" of constant returns to scale, the existence of competitive equilibrium, and the absence of externalities - to calculate the net contribution per year by computers. Using the result of 0.16 percentage point per year as a baseline, they then relax some of the assumptions to see the effect. One assumption is that computers earn the same return as all other capital. When the authors assume a net return of 50 percent to computers, they get double the contribution to aggregate productivity, but this is still minimal. They argue that to assume super-normal returns for IT as a whole is even less plausible than to assume such returns for computers alone because they are skeptical that frictions exist to prevent firms from investing until returns are driven down to the level of other capital. ${ }^{5}$

Brynjolfsson and Hitt (1996b) find "that IT investment has had a significant impact on firm output" at the margin, although they find no evidence of supranormal profits from IT. Brynjolfsson and Hitt (1996a) estimate that the gross rate of return on investment in computers exceeds 50 percent annually in the sample of firms that they analyze. Their productivity findings at the firm level are not inconsistent with Oliner and Sichel's observation that even if IT is productive, it is still such a small fraction of total capital that the gains are not obvious in the aggregate.

The assessment of returns from IT as simply returns to a specific investment in equipment appears to ignore the intuition that IT is revolutionizing work methods. The externalities are precisely what is interesting about IT: the potential for synergism from the increasing networks formed by computers and other information technology. Information technology is transforming the way we work, and the impact of what may be a paradigm shift is likely to extend beyond the direct productivity improvement of the individual piece of equipment. The full effect of this change may not yet be realized. As the workforce learns to use the computer's full 
capabilities, a rapid increase in productivity is likely to occur.

\section{The Diffusion Story}

The third explanation is that computers have not yet been exploited fully. Schumpeter (1951) separated technology improvements into three phases: invention, innovation, and diffusion. The invention of a particular technology may occur long before someone determines a way to incorporate it into a production process as an innovation. If productivity gains are achieved from that innovation, it may take years before other firms observe and copy it. The rate at which this innovation spreads through the industry will be reflected in the industry's productivity growth rate. The share of that industry in total production determines how much the aggregate productivity growth is affected. This is the diffusion story.

It can be argued that the computer can no longer be considered novel, but it is a tool that awaits exploitation. Paul David (1990) offers the diffusion story and takes a historical approach to the phenomenon. He notes that the innovation of the dynamo, the primary electromechanical conversion device, was not immediately recognized as the powerful tool that it was. Decades passed before industry found the multiple uses to which it has since been put. David estimates that it took two decades before dynamo use became widespread. He further points out that new industries were more likely to apply this new technology for mechanizing the factory than were existing firms and industries that waited until existing machinery had depreciated sufficiently. This slow diffusion delayed any impact of the dynamo on productivity until 1920. David suggests that, similarly, we may simply be on the threshold of a revolution in which computers will be used to make gains in productivitythat computers may be on the verge of replacing Ford's mass production as the new paradigm for production.
In Lever of Riches (1990), Joel Mokyr looks at technological creativity and economic progress and concludes that several factors must be in place to achieve innovations and to enhance their diffusion through the economy. He explains England's dominance in the Industrial Revolution as partially due to the human capital in place at the time- not so much the formally educated professionals in which continental Europe had the edge, but in skilled craftsmen and applied engineers who found ways to apply inventions to production and to improve them in the factory setting. In the case of IT, a combination of formal education and application-oriented human capital may be the key to successful transformation of the IT revolution into long-term productivity gains.

Since David's research in 1990, rising productivity growth has occurred in the durables sector of manufacturing. The productivity of the durables sector of manufacturing grew at an average annual rate of 4.9 percent from first quarter 1991 to first quarter 1996. This compares with an average annual growth rate of 2.9 percent the previous five years from first quarter 1986 to first quarter 1991.

To better understand the diffusion story, we can think of how firms make the decision whether or not to invest in new technology. New firms will tend to use the current best available technology, but existing firms must decide whether to abandon old technology and invest in new. As more firms use IT to innovate and these innovations are copied, aggregate improvements will occur. The decision to invest in innovation is not made in isolation but in the context of the environment in which the individual firm finds itself.

\section{HOW LONG DO WE HAVE TO WAIT?}

The period from invention to innovation may be decades. The innovation phase is an application phase that requires adapting the original idea to fit the work- 
place. This process, sometimes referred to as "learning by doing," requires a pioneer or visionary to see how to use the invention and to risk the application. Diffusion of an innovation into the majority of the economy can also take years. If an innovation is successful, institutions, monopoly rights, and profitability will determine how fast the rest of the economy adopts the innovation. At first, very few firms have access to the innovation. Gradually, the technology is acquired by more and more firms until the market is saturated. ${ }^{6}$ And eventually, the technology becomes obsolete and is retired and replaced by new technology.

The rate at which this diffusion takes place determines productivity growth. During the diffusion phase, productivity growth is at its highest. Faster adoption of new technology leads to higher productivity growth. At saturation, growth falls to zero until further technology improvements occur. Lulls between technology changes show up as periods of low productivity growth. Thus to achieve and maintain high productivity growth, both continuous innovation and fast diffusion are desirable.

If diffusion is the key to productivity growth from IT, how soon can we expect this increase in productivity to occur? David (1990) observes that the real gains from the invention of the dynamo took as much as 20 years to show up in aggregate productivity. The electric utilities anecdote suggests a possible five-year lag before the benefits of IT investment can be reaped. It's possible that the gains from IT are al ready beginning to occur. Some industries that had a head start in building IT capital are experiencing productivity gains that might not have been possible without the IT revolution. The current phase of downsizing by major corporations might not have been possible without the increased IT usage.

David's assessment of diffusion of the dynamo has the benefit of 20/20 hindsight, but if M okyr's assessment of the human capital link to technology diffusion in the Industrial Revolution is right, then the factors may be in place for rapid productivity growth. As computers have become more commonplace, computer literacy has increased.

\section{CON CLUSION}

The notion that increased productivity from the IT explosion is on its way is beginning to lose credibility. Despite the proliferation of computers and other information technology hardware, there are reasons to believe that the capabilities are being underutilized. As the labor market increases human capital, greater capacity utilization should occur. This process should, over time, boost productivity growth. Three things give cause for optimism: studies that have identified productivity gains at the firm level; industries like the electric utility industry that demonstrate measurable increases in productivity; and observable but hard-tomeasure increases in the quality of services. Sectoral increases in productivity may not translate into aggregate productivity gains if the displaced labor is not re-employed in an enterprise that is equally productive. Accurately measuring this phenomenon is difficult at best, but continuing efforts to improve statistical data will help. Although anecdotal evidence is not sufficient to prove any conjecture, as the number of anecdotes gets large, we can expect to see confirmation of the effect of IT on productivity in the aggregate data.

\section{REFEREN CES}

Baily, Martin N., Eric J. Bartelsman, and John Haltiwanger. "Downsizing and Productivity Growth: Myth or Reality?" Working Paper No. 94-7, Finance and Economics Discussion Series (April 1994), Board of Governors of the Federal Reserve System.

and Robert J. Gordon. "The Productivity Slowdown,

Measurement Issues, and the Explosion of Computer Power," Brookings Papers on Economic Activity (2:1988), pp. 347-431.

Brynjolfsson, Erik, and Lorin M. Hitt. "Paradox Lost? Firm-Level Evidence on the Retums to Information Systems Spending," Management Science (April 1996a), pp. 541-58.

and . "Productivity, Business Profitability, and Consumer Surplus: Three Different Measures of Information Technology Value," MIS Quarterly (June 1996b), pp. 121-42. 
David, Paul A. "The Dynamo and the Computer: An Historical Perspective on the Modern Productivity Paradox," The American Economic Review Papers and Proceedings (May 1990), pp. 355-61.

Griliches, Zvi. "Productivity, R\&D, and the Data Constraint," The American Economic Review (March 1994), pp. 1-23.

Kunze, Kent, Mary Jablonski, and Virginia Klarquist. "BLS Modernizes Industry Labor Productivity Program," Monthly Labor Review (July 1995), pp. 3-12.

Mark, Jerome A. "Problems Encountered in Measuring Single-and Multifactor Productivity," Monthly Labor Review (December 1986), pp. 3-11.

Mokyr, Joel. The Lever of Riches: Technological Creativity and Economic Progress. Oxford University Press, 1990.

Oliner, Stephen D., and Daniel E. Sichel. "Computers and Output Growth Revisited: How Big Is the Puzzle?" Brookings Papers on Economic Activity (2:1994), pp. 273-334.

Schumpeter, Joseph A. The Theory of Economic Development, Harvard University Press, 1951. 